E-mail: mimidusanovac@gmail.com

Original research article

Received: $18^{\text {th }}$ March 2019

Accepted: $15^{\text {th }}$ November 2019

\title{
THE GRAC - GORNJAK SPRING ARCHAEOLOGICAL SITE IN THE GORNJAK GORGE
}

\begin{abstract}
The remains of the fortifications and sacral monuments in the wider area of the Gornjak gorge that have been explored to date are, in terms of chronology, determined in our science to be from the Late Middle Ages. The results of archaeological surveys, which have been carried out on several occasions in this area, also indicate settlement during the Late Antiquity and Early Byzantine period. Presented in this paper is the Grac - Gornjak spring archaeological site located at the very centre of the Gornjak gorge, and its immediate surroundings. Judging by the collected finds, this site was most probably inhabited during the period from the 4th to the 6th century, without excluding the possibility of settlement during other historical periods.
\end{abstract}

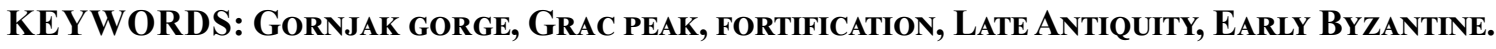

\section{INTRODUCTION}

The first interest of travel writers in the fortifications and sacral monuments in the wider Gornjak gorge area, as far as is known, started during the first half of the $19^{\text {th }}$ century. Travellers' attention was mostly focused on the fortified complex of the medieval town of Ždrelo. In addition to the defensive walls, the first Antiquity admirers who passed through this area left significant data regarding the sacral monuments as well (Миловановић, in print). These include church buildings popularly known as the Metropolitanate, the Annunciation (Blagoveštenje) and Gornjak. Their origin was determined to be in the Late Middle Ages, based on archaeological excavations that were performed between 1979 and 1984. During these explorations, the dating of the settlement of Gornjak gorge was also established for the first time to be in prehistoric times, more precisely, during the Iron Age (Мадас и Гајић
1983, 221-222 1; Цуњак 2000). ${ }^{1}$

The settlement of the Gornjak gorge during the Roman and Early Byzantine periods was first assumed during a field survey of this area at the very beginning of the 1990s. The heads of the research were Mlađan Cunjak and Milorad Miljković. At that time, in front of the so-called Velika pećina (large cave), on the right bank of the Mlava, at the foot of Mali Vukan, a wall was recorded, which, according to the aforementioned researchers, indicates that this place was inhabited during the Roman and Early Byzantine periods. In addition to prehistoric pottery sherds, one Roman coin was also found at this site (Цуњак и Миљковић 1992: 102). ${ }^{2}$

The settlement of Gornjak gorge occurring in the $4^{\text {th }}$ to $6^{\text {th }}$ century has been confirmed at the site

1 During later visits to the Gornjak gorge terrain, findings from the Copper and Bronze Age were also discovered, Стојић и Јацановић 2008: 357.

2 Indications of settlement during the $4^{\text {th }}-6^{\text {th }}$ century also exist on the Šetaće site in the Gornjak gorge on Mali Vukan, $c f$. Јацановић 2013: 14. 


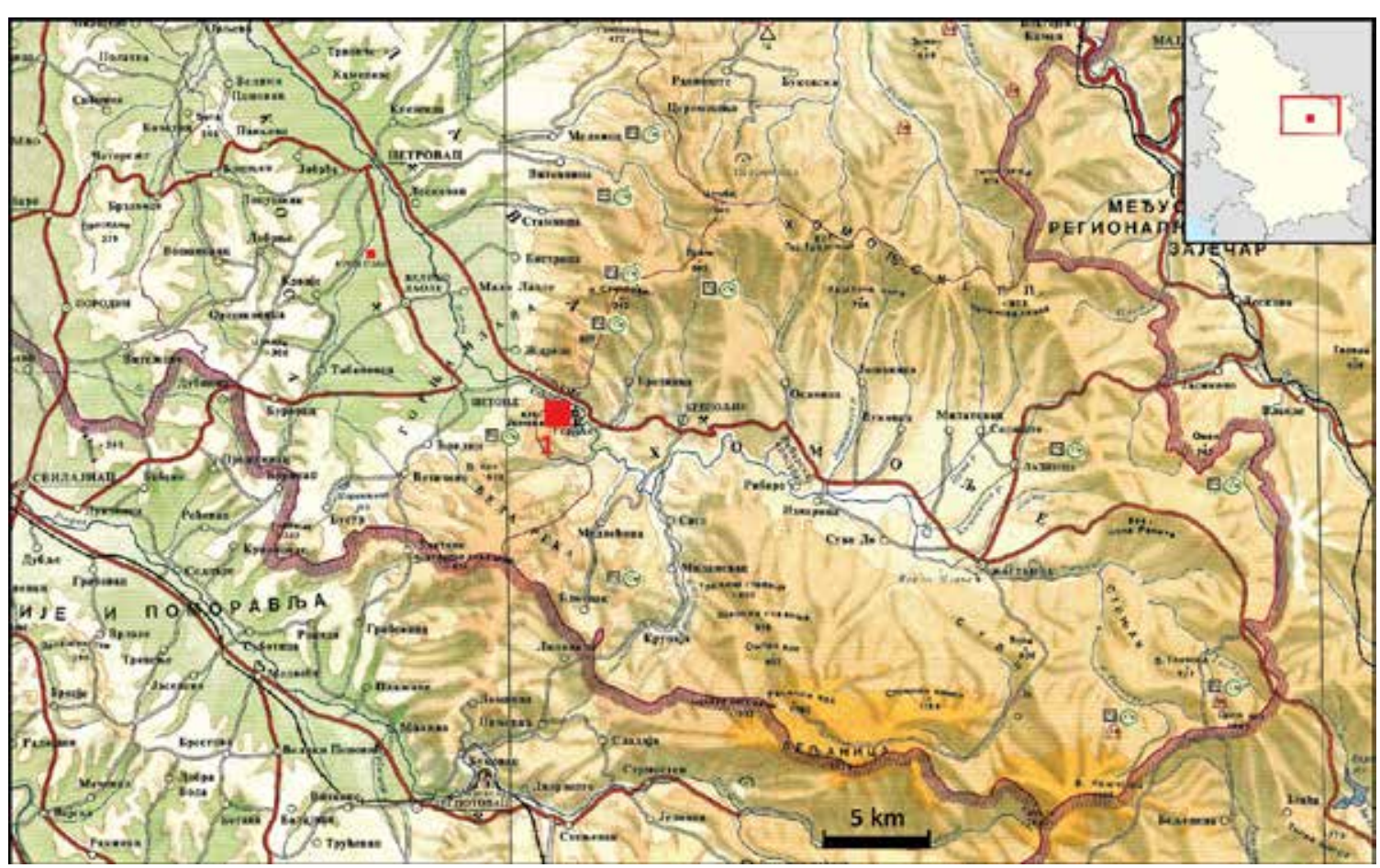

Fig. 1 Grac - Gornjak spring site (1), geographic location.

of the Grac - Gornjak spring, based on recently collected surface finds. To date, there have been no serious attempts to investigate this archaeological site in any more detail. In the literature, this part of the gorge was also referred to as Gradac (Дероко 1950: 114). However, on topographic maps the peak above the Gornjak monastery is marked as Grac. ${ }^{3}$ Unfortunately, the remains of fortifications, now visible in the field, have been largely destroyed by the activities of illegal excavators, especially in the central and southern parts.

\section{GEOGRAPHIC LOCATION OF THE SITE}

Gornjak gorge is located in the southern part of the Braničevo district, at the very entrance to the Homolje micro region. The Mlava river flows through the gorge, intersecting the fertile Stig plain downstream from the village of Ždrelo (Марковић 1988: 81, 150). The nearest town is Petrovac na Mlavi, 14 kilometres to the northwest

3 Edition of the Military Geographical Institute 1970, sheet number $481 / 4,482 / 3$, scale $=1: 50.000$.
(Fig. 1). The Grac - Gornjak spring site is located on the left bank of the Mlava river in the very centre of the Gornjak gorge, next to the Petrovac Žagubica road (Fig. 2). The visible remains of the fortifications were recorded on the eastern slopes of the Grac peak (405 m) which represents one of the peaks of the Ježevac mountain $(675 \mathrm{~m})$ (Fig $3)$. Spread on the right bank of the Mlava river is the Veliki Vukan mountain massif (825 m). These are limestone mountains where layers of red sandstone can be also found (Петковић 1935: 39-42). The site itself is surrounded by the Mlava, except on the western side, from where a rocky limestone massif rises to the Grac peak.

Southwest of the Grac - Gornjak spring site, at a distance of about $400 \mathrm{~m}$, there is the late medieval Gornjak monastery (Fig. 4). Between the monastery and the site is a monastic cemetery whose burial space has been used since the second half of the $20^{\text {th }}$ century. ${ }^{4}$ On the right bank of the Mla-

4 In a discussion with hegumenia Veronika, we obtained information about a legend telling of the original use of this area for the burial of inhabitants of the nearby villages, most probably during the $19^{\text {th }}$ century. The notes of Joakim Vujić, who noticed the monastery cemetery in this place 


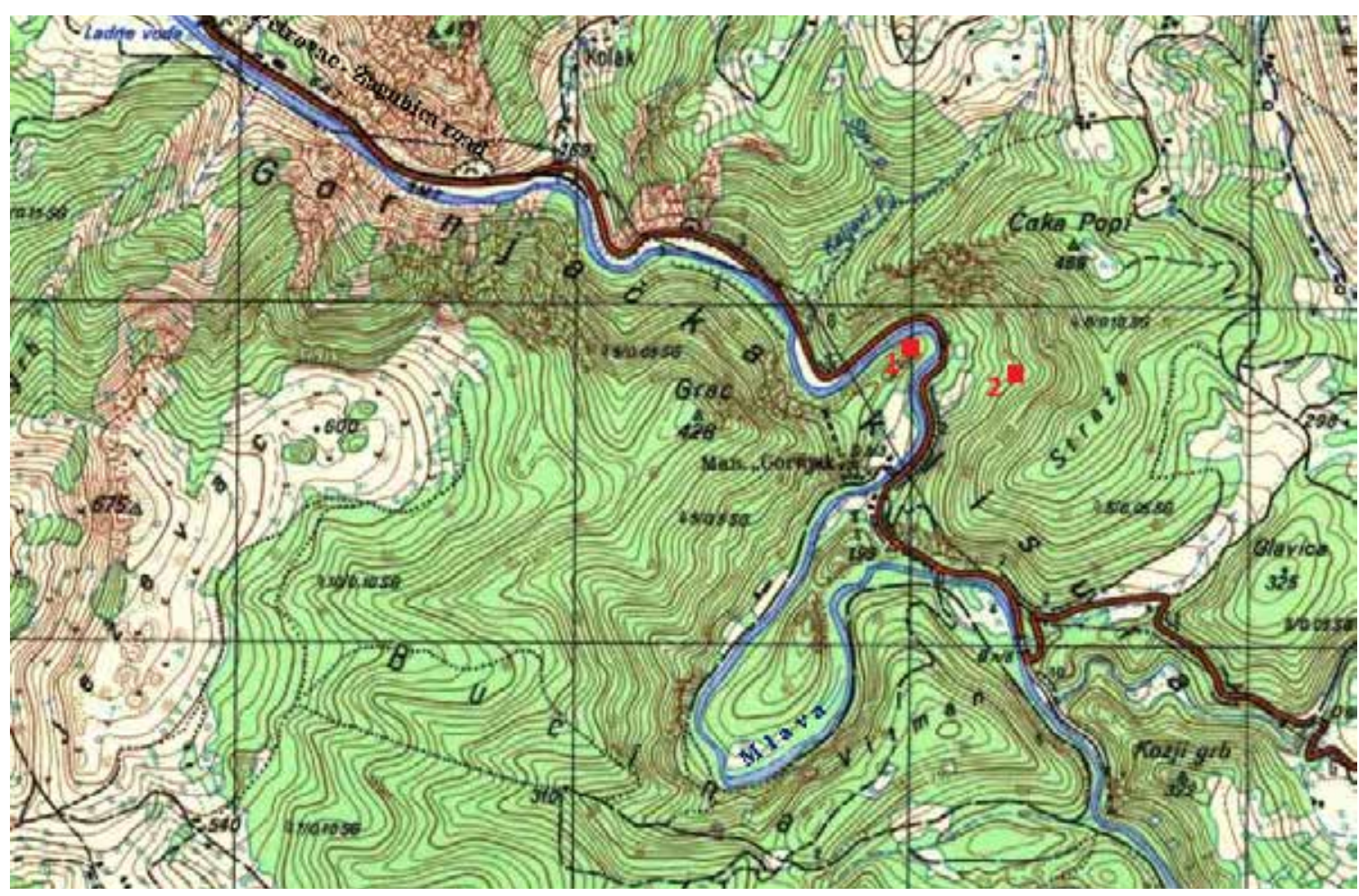

Fig. 2 Grac - Gornjak spring site (1), and Straža (2) site location on a topographic map $($ Scale $=1: 25000$, Edition of the Military Geographical Institute, second edition, 1971, sheet number 482-1-3.)

va river, opposite the place where the remains of the fortifications have been recorded, there is the Gornjak spring, which is currently used for clean drinking water. ${ }^{5}$ The site is overgrown with forest, so the remains of the walls are hardly visible from the road and the spring. Further to the east, the dominant peaks are Čoka Popi (469 m) and Straža (Guard) (400 m). On the western, steep slopes of the aforementioned Straža peak (Fig. 5), visible remains of the architecture were found during field surveys, which will also be discussed in this paper.

\section{SITE EXPLORATIONS TO DATE}

The earliest data about the existence of the ramparts on the left bank of the Mlava river in the

during his visit to the Gornjak monastery in 1826, should also be mentioned (Вујић 1901: 98). Archaeological finds that would indicate a possible chronological determination of this area have not been recorded to date.

5 This spring is also more recently known as the "St. Gregory Spring".
Gornjak gorge, are in the itineraries of the teacher Todor Vlaić, the professor Josif Veselić, and Liceum pupils during the second third of the $19^{\text {th }}$ century. In their notes, information can be found about a certain "town" on Ježevac (Влаић 1850: 32-35; Веселић 1867: 119-121; Поповић 1867: 41). At this moment, albeit is not possible to say with certainty if the travel writers were referring to the remains of the fortifications on the eastern slopes of the Grac peak, or to some other place on Ježevac. Milan Đ. Milićević also mentions the ramparts on the left river bank in Манастири у Србији (Mопasteries in Serbia) from 1867, in which he states that "there are still remains of the towers and old towns on both sides of the Mlava" (Милићевић 1867: 57). In his other work, Кнежевина Србија (Principality of Serbia) from 1876, the clerk of various professions emphasises the existence of the rampart remains on the slopes of Ježevac, descending to the Mlava river (Милићевић 1876: 1032).

Professor Jovan Dragašević visited the left bank of the Mlava while studying the valleys and 


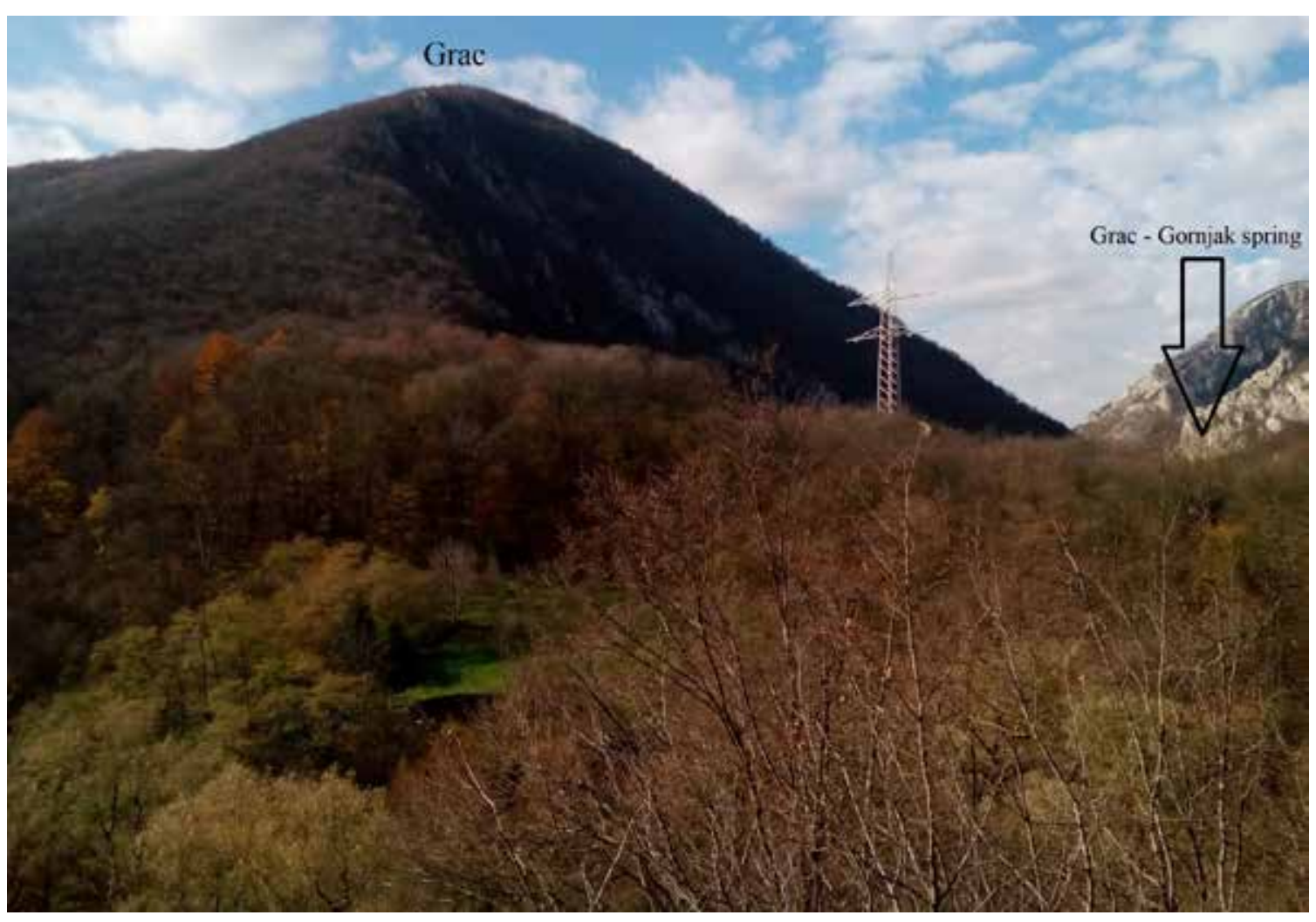

Fig. 3 A view of Grac peak from the western slopes of Straža peak.

mountains at Homolje, beginning in 1872. In his notes can be found information on the ramparts situated "within a stone's throw of Ježevac" (Драгашевић 1876: 312-313; Драгашевић 1874: 60-61, 63). In addition, Vladimir Karić, a jurist, mentions the fortifications along the Mlava river in the Gornjak gorge. In his paper from 1887, he wrote about dividing walls and towers located close to the river in the Gornjak gorge (Карић 1991: 38, 849). Felix Kanitz also provides similar data. During his visit to the gorge in the last quarter of the $19^{\text {th }}$ century, he noticed the walls of the strong fortifications on Ježevac close off Ždrelo in Braničevo (Каниц 1985: 266). However, based on the observations of writers from the second half of the $19^{\text {th }}$ century, it cannot be said with any certainty whether they left in their records information on the wall of the Grac - spring in the Gornjak gorge.

The site was mentioned for the first time under the name Gradac, by Aleksandar Deroko in 1950. It was recorded that $15 \mathrm{~km}$ from Petrovac na Mlavi to the south there are remains of a town (Дероко 1950: 114). Subsequent interest in the fortifications on the eastern slopes of Ježevac occurs during the 1950s. At that time, the Gornjak gorge was the subject of interest of Nikola Krstić (Fig. 6), a physical education teacher from Petrovac na Mlavi (Јацановић и Живковић 2000: 111, 120) and an associate of the Požarevac Museum (Dragojević 1983: 55). Nikola Krstić also named the site, which is the subject of this paper, Gradac. In his notes, among other things, he also wrote: "A lot has been written about Gornjak. However, it has not been recorded that on hills overgrown by woods, around which the Mlava bends, there are the remains of the walls of some fortification. The most striking are the remains of the Gradac walls, which are located on the conical hill rising above the monastery. It is difficult to reach those ruins, because there is no road to the top of the hill, which is overgrown by thick forest. People believe that these green mossy walls are the hermitage of Saint Gregory of Sinai" 


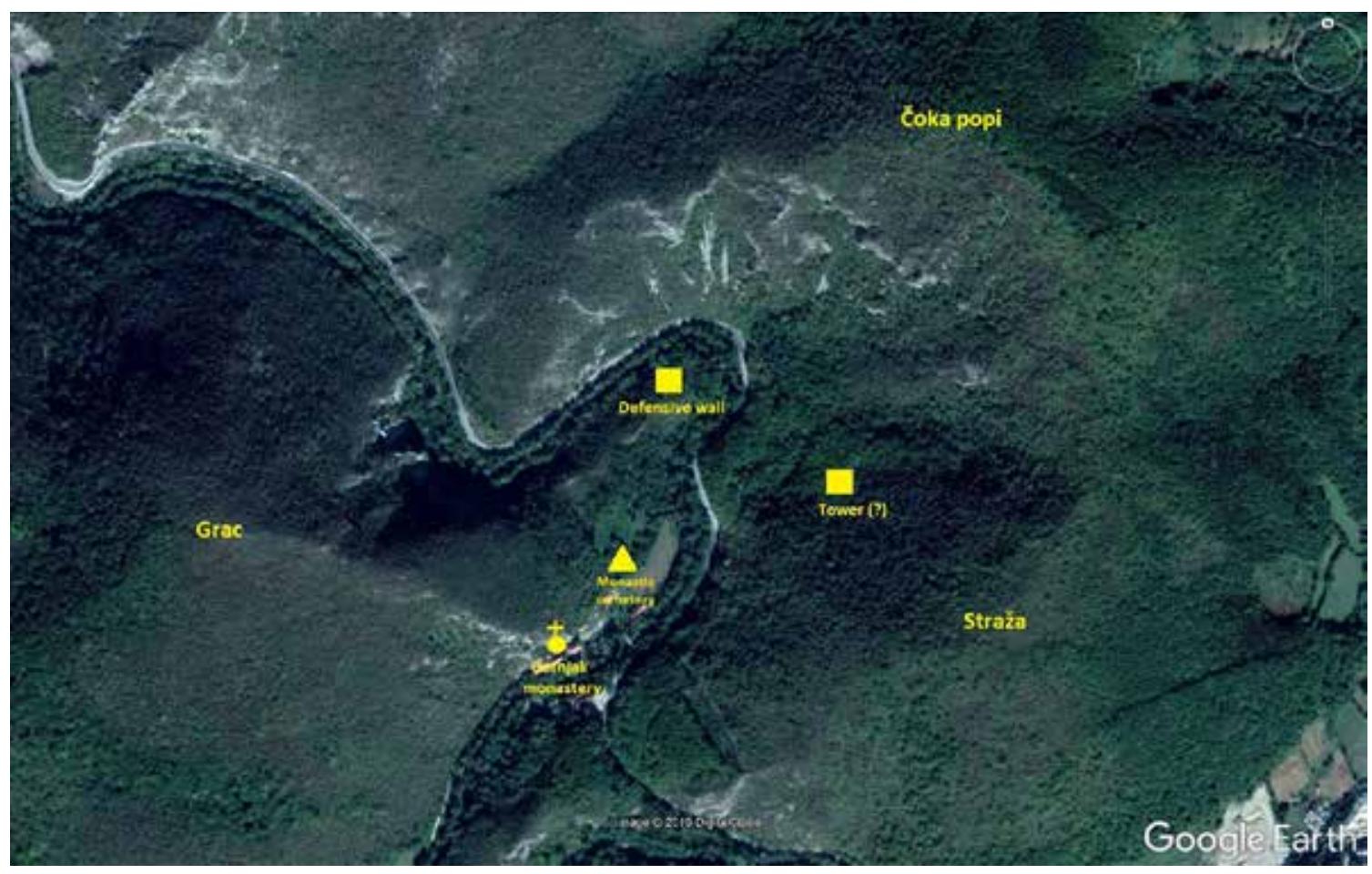

Fig. 4 A wider surrounding of the Grac - Gornjak spring site.

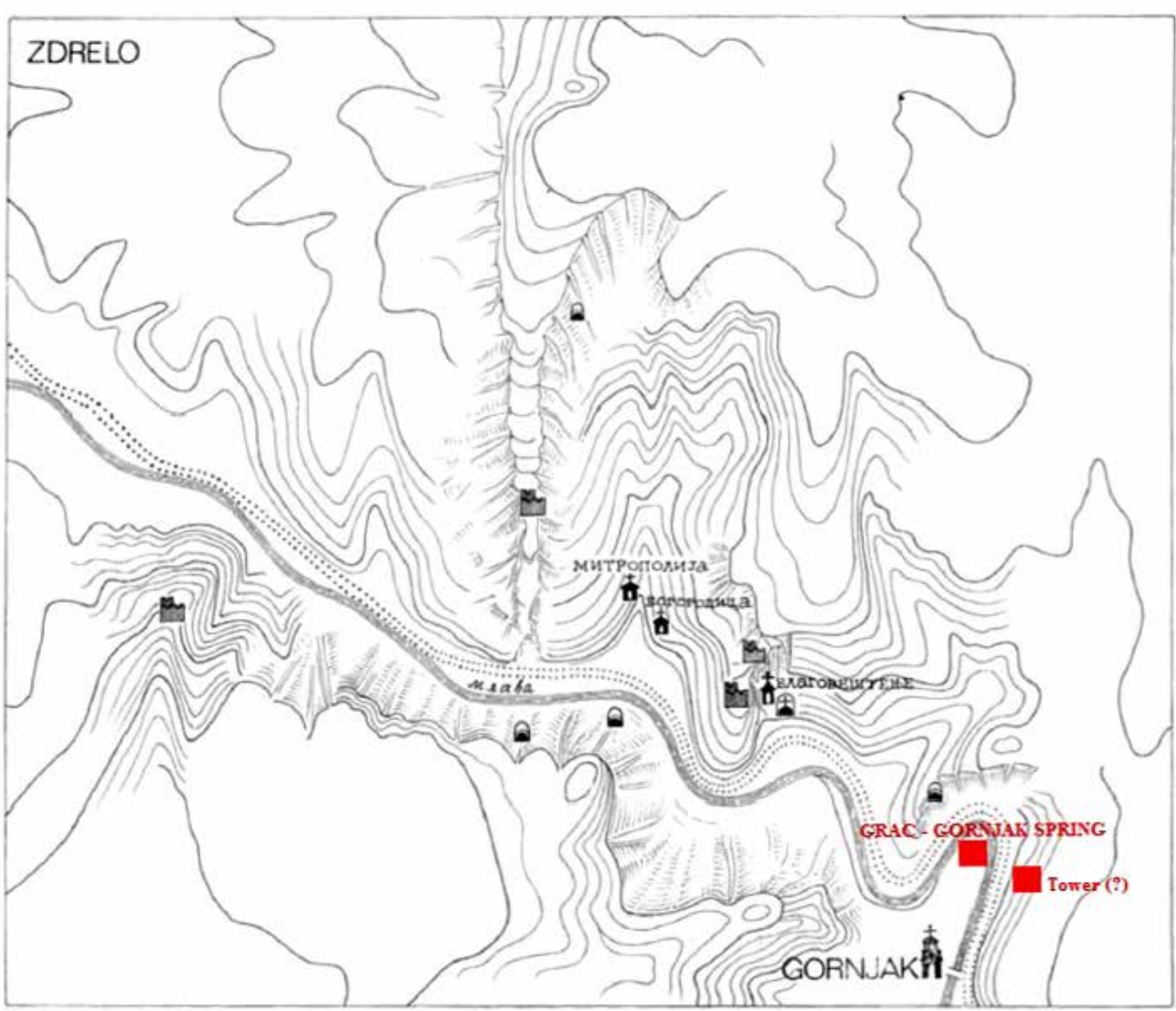

Fig. 5 Location of the Grac - Gornjak spring site and Straža in relation to the fortifications and sacral buildings explored and registered so far in Gornjak gorge (According to: Мадас и Гајић 1983: 240). 
(Јацановић и Живковић 2000: 126).

Visits to the Grac - Gornjak spring site were carried out in the period between 1979 and 1981, when remains of the smaller fortification were recorded. During these years, excavations of the Late Middle Age sacral buildings on the foothills of Mali Vukan were also performed (Мадас и Гајић 1983: 222). The area of the Gornjak gorge was also surveyed at the beginning of the 1990s by M. Cunjak and M. Miljković. Judging by the brief report, the fortification remains are recorded on Ježevac, but it cannot be concluded based on the presented data if the ramparts by the left bank of the Mlava were the aim of this visit (Цуњак и Миљковић 1992: 101-102).

Several findings from this site were published for the first time in the book Насеља Браничева. Географско - археолошко - историјска монографиjа (Braničevo Settlements. Geographic - Archaeological - Historical Monograph) by Ben Mladenović and Dragan Jacanović from $2002 .{ }^{6}$ These are pottery vessels which, according to their shape, might belong approximately to the Late Antiquity. ${ }^{7}$ The site itself is characterised

6 For the time being, we do not have adequate information indicating exactly when the Grac - Gornjak spring site was registered for the first time by the archaeologists from the National Museum in Požarevac, $c f$. Јацановић 2013: 1314. In the report on the work of the Požarevac museum for 1999, there is information that at that time the Gradac site in Krepoljin (?) was registered, during the realisation of the Old Cultures of Homolje project. In addition, the Gradac site in the village of Ribar was recorded, Манојловић 2001a: 329-330; Манојловић 2001b: 332. At this moment it is difficult to determine if Gradac in Krepoljin is actually the site in the Gornjak gorge on the left bank of the Mlava, described by N. Krstić. It should be noted that the property of the Gornjak monastery, according to certain authors, is also located in Krepoljin, Радовановић 1997: 241-242, 255; In this case, it cannot be ruled out that the Grac Gornjak spring site was also visited during the realisation of the Old Cultures of Homolje project. Final confirmation of this will be obtained when the entire report from these studies is published for an academic audience, and the report on the work of the Požarevac Museum for 1999 is supplemented in a more detailed and precise manner.

7 The vessel sherds originate from illegal excavations. They were collected in 2000 by D. Jacanović. Detailed information about this visit is not known, Миловановић 2016a: 118 .

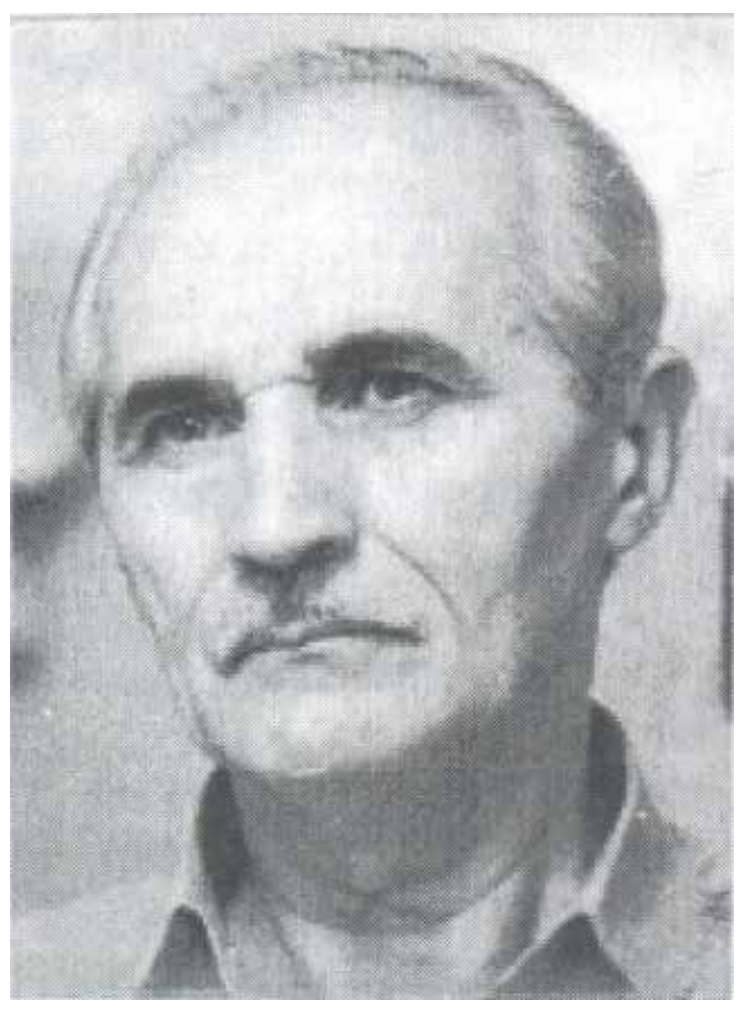

Fig. 6 Nikola Krstić, antiquity admirer from Petrovac na Mlavi and in his time associate of the Požarevac Museum.

as a Roman metallurgy centre (Младеновић и Јацановић 2002: 122, 129). A survey of the Grac - Gornjak spring site was conducted in 2015 by the signatory of this text. On that occasion, a short tour of the eastern slopes of Ježevac was carried out, as well as of the foothills of the Čka Popi peak and the slopes of the Straža peak on the right bank of the Mlava river. Across from the Gornjak spring, on the slopes of the Grac peak, the fortified wall was examined (Fig. 7), and illegal excavations were also recorded (Миловановић 2016a: 42-43). A report from these brief field surveys was submitted to the National Museum in Požarevac. ${ }^{8}$ A smaller number of atypical pottery sherds found during the visit was handed over to the Homolje Homeland Museum in Žagubica. ${ }^{9}$

8 Report 413 and 419, National Museum of Požarevac, No. 843, 12/12/ 2016.

9 Official note No. 11, 16/01/2018, Homeland Museum of Homolje in Žagubica. 


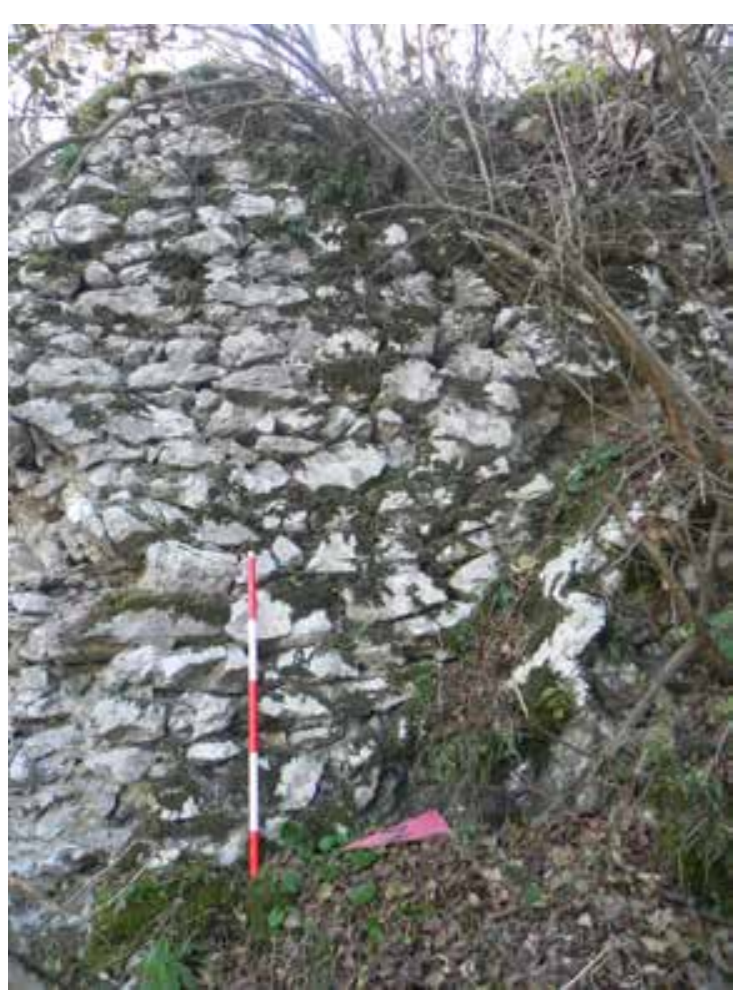

Fig. 7 The outer face of the defensive wall.

\section{FORTIFICATION REMAINS AND PRESENT CONDITION}

The remains of the fortifications at the Grac - Gornjak spring site are located at an altitude of about $160 \mathrm{~m}$. They are reached by a path next to today's monastic cemetery, which is located in front of the Gornjak monastery. The path further leads to the limestone ridge on which the site is located, around which the Mlava makes a bend. At the top of the ridge is a smaller flattened plateau. To the north, there are remains of fortifications from which the slope gradually descends towards the Mlava. On the eastern side of the plateau is a sharp cliff, while on the western side are the slopes of the Grac peak. Slightly milder slopes are on the southern side where access to the site is the most convenient. From the top of the plateau, there is a view towards the Gornjak monastery yard and the mountain peaks of Mali Vukan and Ježevac.

The orientation of the preserved defensive wall is north - south (Figs. 8, 9). Its southern side

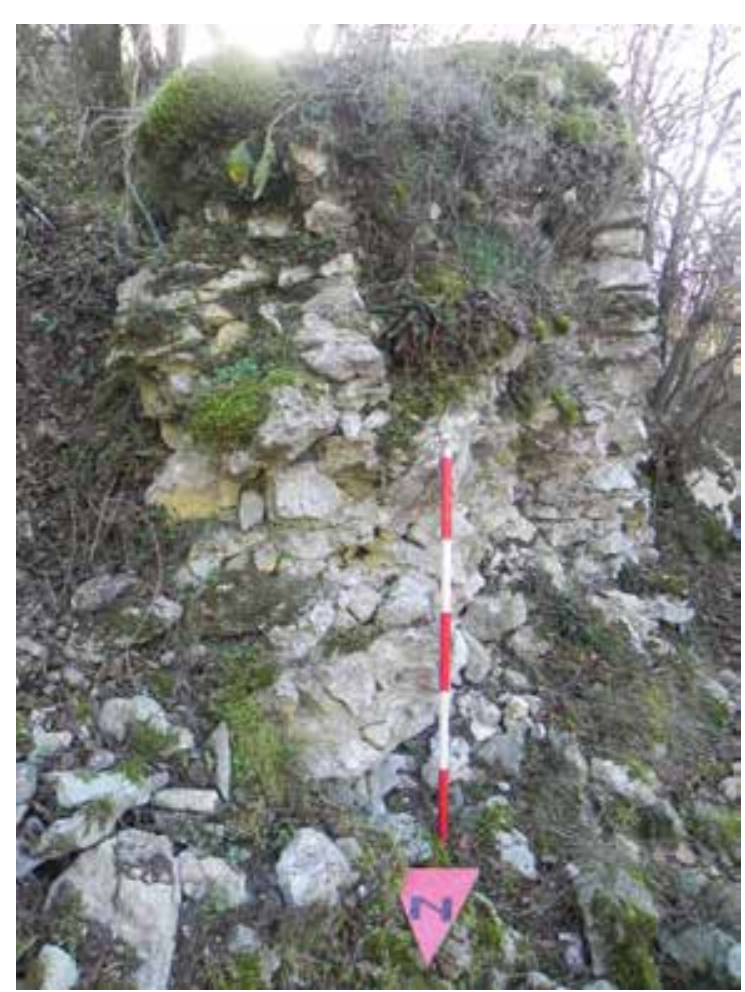

Fig. 8 Damage to the defensive wall on the northern part.

was built on a rock of the ridge below the plateau itself. From there, the route of the wall is adapted to the configuration of the terrain and follows the surface of the slope, which gradually descends towards the Mlava. The length of the preserved building is $12.85 \mathrm{~m}$. The maximum preserved external height is $4.90 \mathrm{~m}$, the inner height is $1.25 \mathrm{~m}$, while the thickness is $1.60 \mathrm{~m}$. The wall is made of broken and cut limestone, which is bound with a lime mortar of a whitish colour (Figs. 10, 11, 12). Traces of unauthorised digging can be observed on the inner side of the wall and in its immediate vicinity. The wall itself has been damaged in the northern and southern part by illegal searchers (Figs. 8,13). The greatest damage to the wall is in the central part, where a large opening of an elongated irregular semi-circular shape was created by the illegal activities. The width of the opening is $1.04 \mathrm{~m}$, while the height is $1.22 \mathrm{~m}$. The rampart route below ground level can be followed for another $2 \mathrm{~m}$ in a northerly direction. Within the outer face of the wall, in the upper part, a smaller 


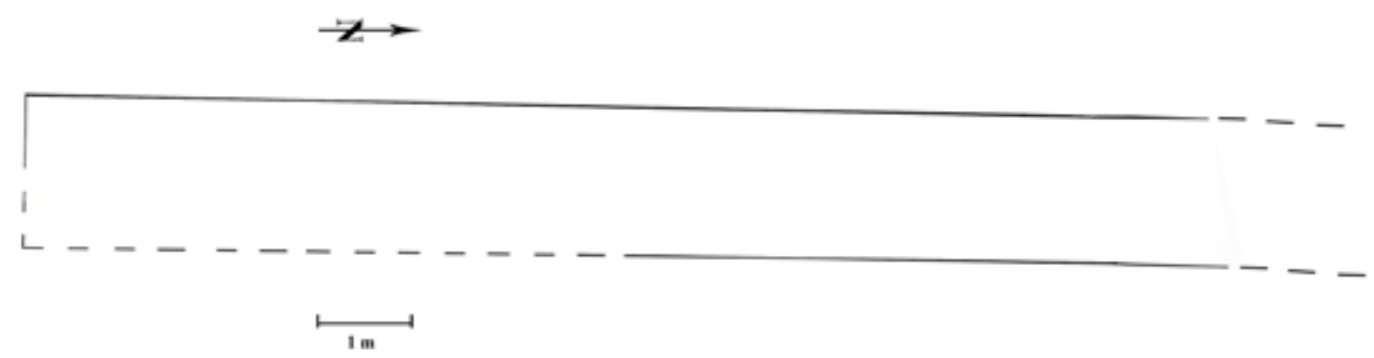

Fig. 9 Drawing of the defensive wall.

opening of an irregular square shape measuring $15 \times 15 \mathrm{~cm}$ (location for a well fence?) can be observed. In addition to the dense vegetation, the site was largely covered with fallen leaves during the 2015 visit, so no visible traces of architecture were observed in the wider area. It should be noted that the terrain configuration at the base of the described wall, towards the Mlava, indicates the possible existence of remnants of the walls below ground. During the visit, a smaller number of atypical fragments of Late Antiquity pottery and one tegula sherd were found.

At this point, a brief overview of the closer surroundings of the Grac - Gornjak spring archaeological site is in order. First of all, reference is made to the reports of a teacher, Mihajlo St. Riznić, from 1885. While visiting the Gornjak monastery and its surroundings, he recorded the legends he had collected from the monks and locals of this region about Prince Lazar and St. Gregory. The tale, among other things, says that the Serbian prince built a cell for a hermit on Ježevac, before going to the battle of Kosovo (Ризнић 1886: 60). The information about some ruins of a cell and a church in Ježevac, recorded by Riznić and not studied to date, are of particular importance to us (Ризнић 1886: 60; Миловановић, in print). It is difficult to say where the ruins of these sacral structures were, since the entire area of this mountain, together with the wider surrounding area, have not been fully examined to date.

It is worth reminding ourselves, for a moment, of the story of St. Gregory, recorded by N. Krstić in the 1950s. After describing the location of the Gradac site, that is, the Grac - Gornjak spring, he wrote that the people believe that these walls, covered with green moss, are the hermitage of St. Gregory of Sinai (Јацановић и Живковић 2000: 123, 126). Is M. St. Riznić considering this place on Ježevac when he talks about the ruins of sacral buildings? As a member of the Serbian Archaeological Society and an associate of the journal Starinar, ${ }^{10}$ he visited the archaeological sites in the Zvižd area where, among other things, he also recorded the sacral buildings. Together with descriptions of some sites, he also provided sketches of churches, such as in the wider area of the Čukarelja site in Kaona (Ризнић 1888: 37-38, T. V). Based on his published reports, it can concluded that Riznić knew very well how to recognise the church buildings that were in the ruins. However, today the supposed remains of the sacral buildings in the Grac - Gornjak spring site are not identified.

It is necessary to also draw attention to the walls below the top of the Straža peak, on the right bank of the Mlava river, which are about $250 \mathrm{~m}$ from the Gornjak spring in a south-easterly direction. The remains of the architecture are recorded on the steep, western slopes of the peak and are visible from the Petrovac - Žagubica asphalt road (Fig. 14). The altitude of the site is about $200 \mathrm{~m}$. The preserved wall is oriented north - south, made of broken and cut rubble, and bound with lime mortar of a whitish colour. Its length is $5 \mathrm{~m}$, its preserved height is $2 \mathrm{~m}$, and its width is $0.70 \mathrm{~m}$ 10 See journal Starinar for 1884 , page 5. 


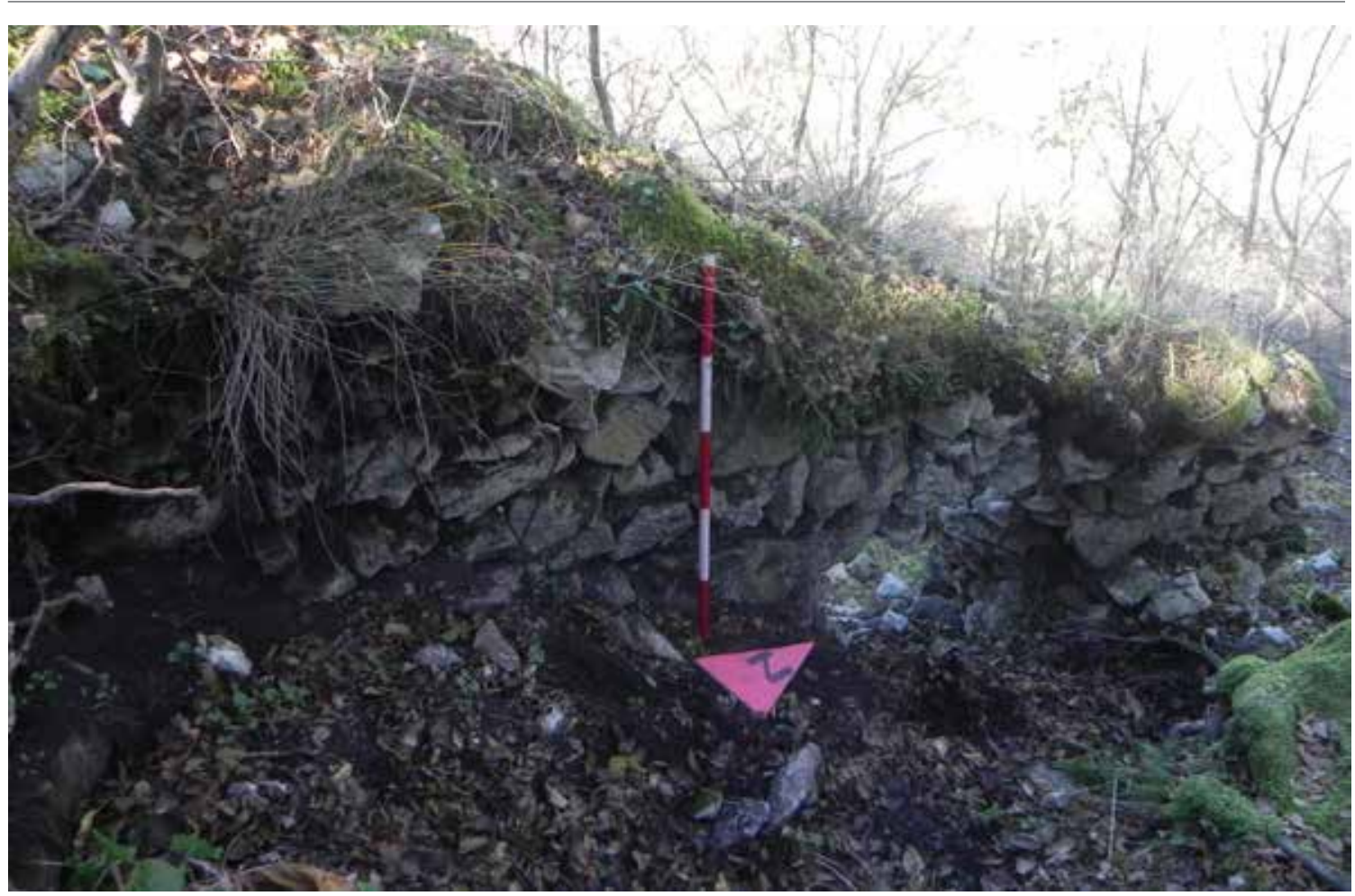

Fig. 10 The inner face of the defensive wall with visible traces of damage.

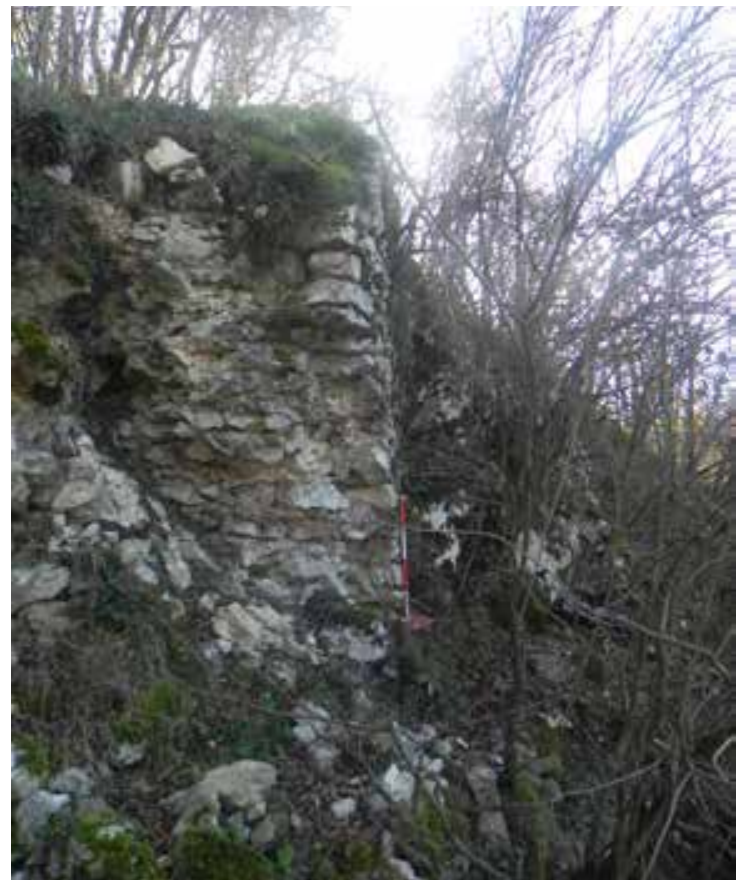

Fig. 11 Damage to the defensive wall in the middle part.

(Миловановић 2016b: 18-19, сл. 8). ${ }^{11}$ This place

11 See also Report No. 413, National Museum of Požarevac, No. 843, 12/12/2016; See also the topographic map scale $=1: 25000$, Edition of the Military Geographical

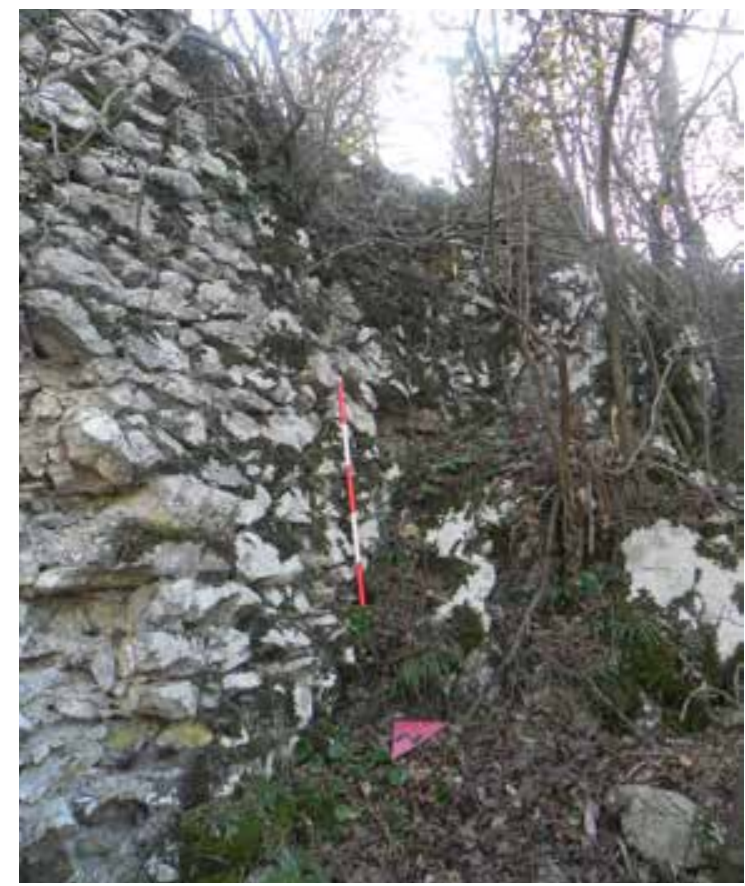

Fig. 12 The external face of the defensive wall at the central part.

can be reached through the north-western, milder slopes of the Straža peak. Between the road and the walls, there is a sharp, impassable slope, while on Institute, second edition, 1971, sheet number 482-1-3. 


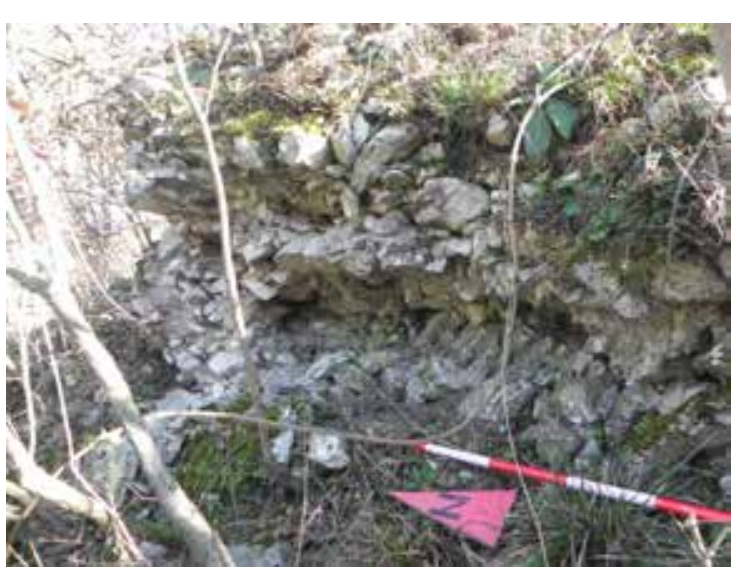

Fig. 13 Damage to the southern part of the defensive wall at the external face.

the opposite side there is a smaller plateau above which the vertical cliffs rise. The place where this wall is located was skilfully selected, since it provides a view to the peaks of Ježevac and Mali Vukan. It is possible that these are the remains of some observation tower, which was included in the wider fortification system at the Grac - Gornjak spring site. Both the terrain configuration and the Straža toponym itself lean in favour of this assumption. When visiting this area, no archaeological finds were discovered that would indicate the probable chronological determination of the wall.

The reason for the construction of the defensive wall at the Grac - Gornjak spring site remains, for the time being, in the domain of assumptions. At this moment, the entire fortification's dimensions or the exact time of construction are not available, so it is difficult to talk about the possible type of fortified settlement, as long as archaeological excavations are being carried out. ${ }^{12}$ It is possible that these walls, together with the supposed observation tower on the Straža mount, formed a joint fortified complex. The publication of the entire archaeological surveys report of this site performed by colleagues from the National Museum in Požarevac would be of great benefit to science (Јацановић 2013: 13-14). ${ }^{13}$ It is a distinct possibility that the defensive wall in front of the Gornjak monastery

12 The possibility that the dividing wall sloping to the Mlava river (?) is in question here should not be ruled out. 13 See footnotes No. 6 and 7 in this paper.

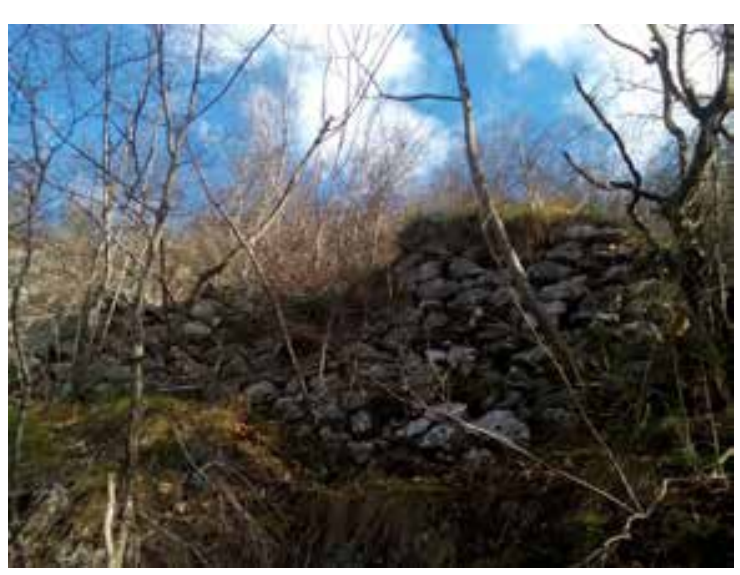

Fig. 14 Wall remains at the western slopes of the Straža peak.

was in better condition during these visits than it is today. It should not be ruled out that there were some other structures that were most likely visible on the terrain at that time. The site itself is defined as a Roman metallurgical centre (Младеновић и Јацановић 2002: 129) which is probably to be concluded from archaeological finds discovered on the surface of the site (slag, vessels, mining tools?).

\section{FINDS}

To date, two vessels from the Graz - Gornjak spring site have been presented to the public, which, based on their shape, may belong to Late Antiquity. ${ }^{14}$ These are a pot and an amphora (Fig. 15/1-2). Based on the attached photo, it can be concluded that the pot had two handles, of which one is completely preserved. The handles are located at the junction of the upper belly and the shorter neck below the rim. The rounded belly gradually descends to the smaller base. The rim of the vessel was probably profiled. Since data is only available about the vessel shape, final conclusions must be taken with reservations when it comes to dating. Judging by the shape, analogies can be found in Singidunum, where such specimens of pots are roughly determined to be in the

14 These are photos without scale. We also do not have data with a more detailed description regarding the quality of pottery and baking colour of these vessels, cf. Младеновић и Јацановић 2002: 122, 129. 
period from the middle of the $2^{\text {nd }}$ to the beginning of the $5^{\text {th }}$ century. According to the typology set forth by Snežana Nikolić-Đorđević, a specimen from the Graz-Gornjak spring site could most likely belong to type II/9. Usually, vessels of this type are made of sandy clay, with a yellowish or white baking colour. The handle is mostly ribbed, while the dimensions themselves vary from the size of pithoi, to quite small, miniature vessels. Pots of this typological group may also have one handle (Nikolić-Đorđević 2000: 69-70, 211, Tip II/9).

The amphora from the Graz - Gornjak spring site has a slightly funnel-shaped neck. The shoulders and neck of the vessel are connected by two handles. The belly is approximately ball-shaped and gradually descends to a smaller base. The rim, according to the attached photograph, was probably profiled (Fig. 15/2). As in the first case, the proposed dating must be taken with caution, since no information is available to facilitate a chronological determination. According to the typology of Ljiljana Bjelajac, it is possible that they are locally produced amphorae, which should most likely be classified in type XXXII (Bjelajac 1996: 101-103, sl. XXXVI, kat. 200-203). This type of vessel is characterised by a profiled rim and twisted handles, which can also have a circular cross section. The belly is spherical or oval, while the base is straight or concave. The height of these vessels is between 40 and $50 \mathrm{~cm}$ and the baking colour is grey or reddish. Amphorae of this type are dated roughly between the $4^{\text {th }}$ and $6^{\text {th }}$ century. They have their origins in the locally produced amphorae of the $2^{\text {nd }}-3^{\text {rd }}$ century and, therefore, $\mathrm{Lj}$. Bjelajac assumes their continuous production in the area of the Upper Moesia, Danube region (Bjelajac 1996: 101-102). Territorially, the closest analogies to vessels with local production of this type can be found in Viminacium, whose vessels were recorded as being in the layers of the $4^{\text {th }}$ century. Some specimens were also discovered at the fortifications in Đerdap within the same cultural strata (Bjelajac 1996: 102-103, sl. XXXVI/199, kat. 199; Jevremović 1987: 51, T. XI/IV/1).
In addition to the above-mentioned vessels, some pottery fragments originating from this site can be dated approximately, with some caution to the late antiquity or the early Byzantine period. These are fragments of pots and pithoi. ${ }^{15}$ Several fragments of pots have been collected, and for this occasion one has been selected for which it can be said with certainty that it belongs to the period from the $4^{\text {th }}$ to the $6^{\text {th }}$ century. The fragment is made of dark grey clay with some quartz. Even though this pot type occurs at late antiquity sites, certain analogies point to its production during the early Byzantine period as well. The form of this fragment has similarities with pots found within late antiquity layers at the Đerdap fortifications (Цвјетићанин 2016: 89, тип Л/53; Кораћ 2018: 89, сл. 35/66). A pot fragment with a similar rim was found at the Jerinin grad - Gornja Crnuća site in the vicinity of Gornji Milanovac. This vessel is chronologically determined to be from the end of the 4 th and the beginning of the $5^{\text {th }}$ century (Лудајић, Поповић и Милинковић 1986: 87, T. VIII/1-2). When it comes to early Byzantine archaeological sites, parallels with the pot fragment from Grac can be found in the Liška ćava fortified settlement near Guča (Радичевић 2006: 42, 44, сл. 6/3-4). It seems that we also have analogies at the Viča - Stojkovića Gradina archaeological site, which is also near Guča. During test excavation, a pot was found within early Byzantine cultural strata, which by its shape and form has certain similarities with the specimen discovered in Grac. (Марковић, Петрашиновић и Лудајић 1986: 69-70: T. IV/2). Vessels of this type which belong to the older phases of pottery production on this early Byzantine site were also found in the Caričin grad site (Bjelajac 1983: 55, TIP I/16). However, the closest territorial analogies to the pot can be found at the Pregrada - Podkrš site in Žagubica. Based on micro-location and accidental finds, it is assumed that this site existed during the 6th century (Миловановић 2016а: 138, T. VIII/6; Миловановић 2017: 33, 44, сл. 10/1;

15 The objects are kept in the National Museum in Роžarevac, cf. Миловановић 2016a: 7, 41. 

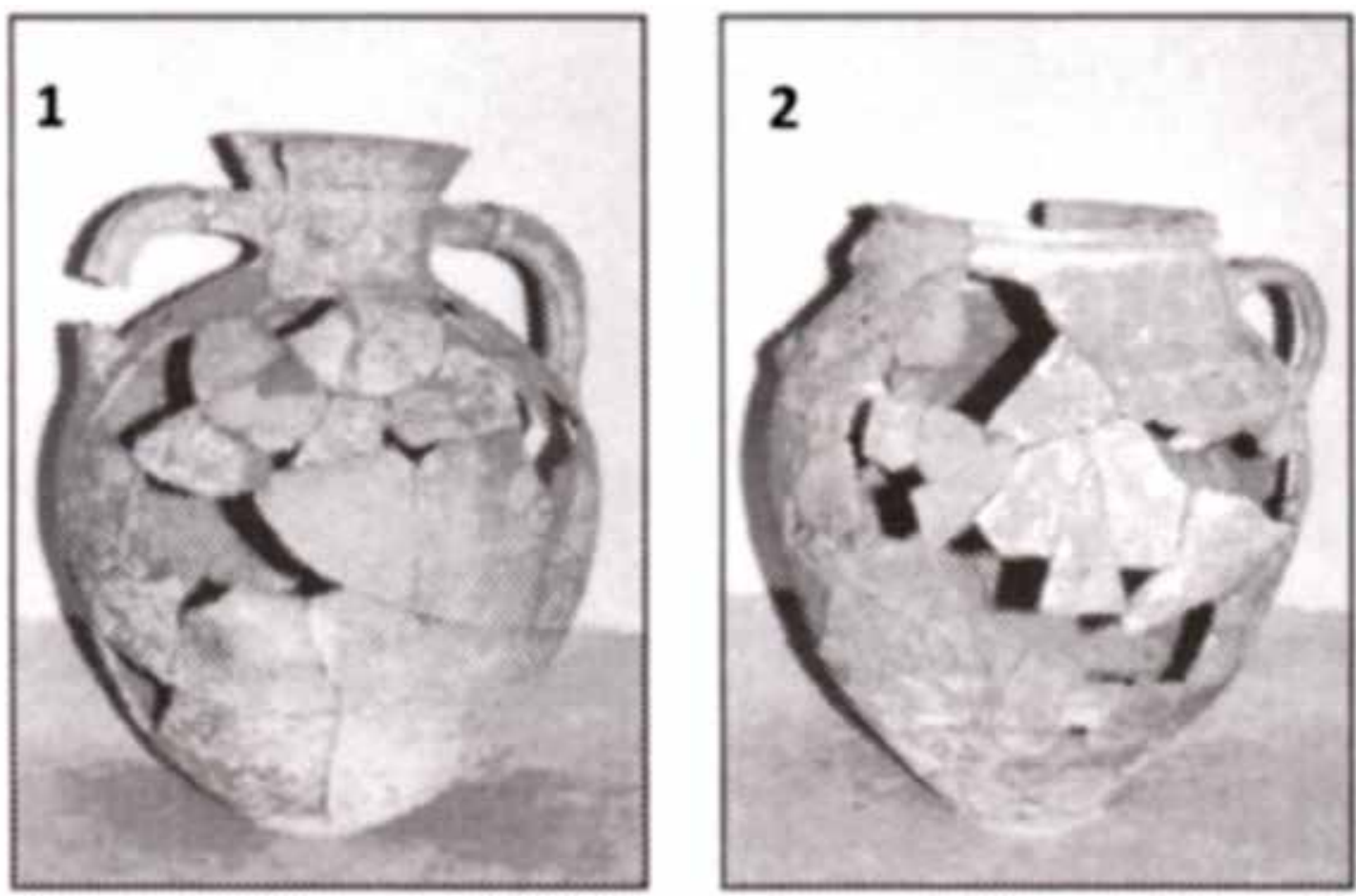

Fig. 15 Pottery vessels from the Grac - Gornjak spring site (Аccording to: Младеновић - Јацановић 2002, 122).

Милинковић 2015: 55: сл. 13).

A fragment of a pithos from the Graz - Gornjak spring site has a flat rim with a thickened and rounded mouth. Below the flat rim, a semi-circular projection extends along the entire inner surface of the rim. The neck of the vessel is short, and the walls are thick (Fig. 16/2). It is clay with mixtures of quartz and sand, with a light grey baking colour (Миловановић 2016a: 118, T. VIII/4). Similar pithoi sherds were accidentaly found at Pčelinji krš near Žagubica (Миловановић и Филиповић 2018: 3-4, 34, кат. 58). That is the site that had been settled in the period from the $4^{\text {th }}$ to the $6^{\text {th }}$ century (Мишић и Селаковић 2018: 19), with the assumption that the fortifications that remain visible today were built during the great Justinian restoration after 527 AD (Миловановић 2018a: 10; Milovanović 2018b: 29: ref. 2). One pithos fragment also originates from the above-mentioned Pregrada - Podkrš site in Žagubica (Миловановић и Филиповић 2018: 4, 35, кат. 62). Analogies for this type of pithos have been found within the early Byzantine cultural strata at Gradina above
Pazarište, near Novi Pazar (Popović 1999: 106 sl. 54/4, kat. br. 54/4.).

\section{CONCLUSION}

The archaeological site of the Graz - Gornjak spring, according to accidentally discovered findings, testifies to the settlement of this part of the Gornjak gorge during the period of the $4^{\text {th }}$ to the $6^{\text {th }}$ century (Јацановић 2013: 13-14). Since a pot from the site can also be determined to be in an earlier period, on the basis of the attached photograph, it should not be ruled out that this part of the gorge was inhabited even during the antiquity period. Travellers from the second half of the $19^{\text {th }}$ century left information regarding the fortifications on Ježevac and the left bank of the Mlava river, but it cannot be said for certain whether they visited the wall presented in this paper. Nikola Krstić provided the most significant information on the location of this archaeological site in the 1950s. It is possible that his notes led experts from the National Museum 


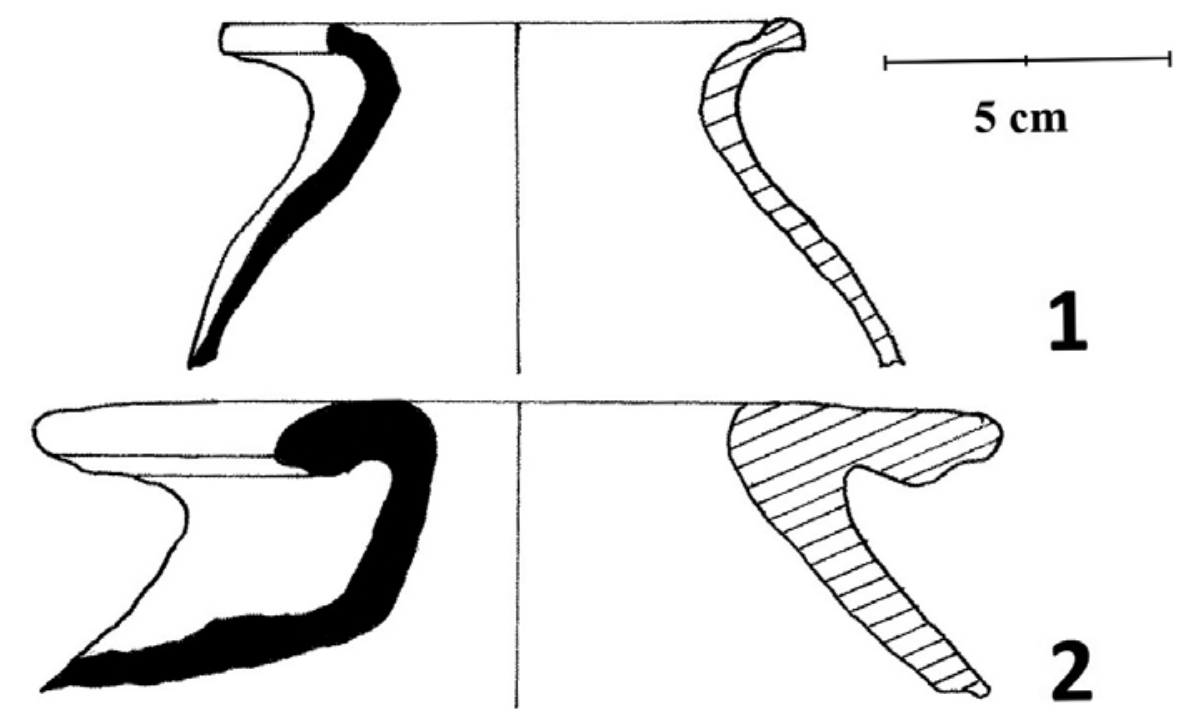

Fig. 16 Pottery sherds from the Grac - Gornjak spring site: a pot (1), a pithos (2).

in Požarevac to make a survey of this area, which was most likely conducted in 1999. Photographs of the vessels, as well as the provided sherds, indicate settlement of this part of the Gornjak gorge between the $4^{\text {th }}$ and the $6^{\text {th }}$ century, noting that continuity of life there during other periods of history is also possible. At this point, it is difficult to determine the type and overall surface of the supposed fortified settlement not far from the Gornjak monastery. As the site is prone to destruction by illegal searchers, the primary aim of this paper is to point out the need for protective archaeological excavations so that the remains of the fortifications will not be completely destroyed and the cultural layers disturbed. The indications of the existence of sacral monuments and necropolises on this site should not be forgotten, though they have yet to be studied in an archaeological context. The same is true of the wall discovered at the top with the indicative name Straža (Guard), across from the Gornjak spring, on the right bank of the Mlava. For the time being, there is no evidence suggesting that this area was inhabited during the medieval era. Only future archaeological excavations will provide answers as to whether the remains of the fortifications on the eastern slopes of the Grac peak and its immediate surroundings were in use during the Middle Ages, when the nearby Ždrelo fortress was mentioned in written sources.
Arheologija i prirodne nauke (Archaeology and Science) is an Open Access Journal. All articles can be downloaded free of charge and used in accordance with the licence Creative Commons - Attribution-NonCommercial-NoDerivs 3.0 Serbia (https://creativecommons.org/licenses/bync-nd/3.0/rs/.

Časopis Arheologija i prirodne nauke je dostupan u režimu otvorenog pristupa. Članci objavljeni u časopisu mogu se besplatno preuzeti sa sajta i koristiti u skladu sa licencom Creative Commons - Autorstvo-Nekomercijalno-Bez prerada 3.0 Srbija (https://creativecommons.org/licenses/bync-nd/3.0/rs/.

\section{BIBLIOGRAPHY}

\section{Bjelajac, Lj. 1983}

Keramika Caričinog grada, Magistarski rad, Filozofski fakultet. Univerzitet u Beogradu.

\section{Bjelajac, Lj. 1996}

Amfore gornjomezijskog Podunavlja, Posebna izdanja 30, Beograd: Arheološki institut Beograd. 


\section{Веселић, J. 1867}

Описъ монастира у Србіи, Часть I, Београд: Кньигонечатия А. Андрића.

(Veselić, J. 1867

Opis“ monastira u Srbii, Čast,, I, Beograd: Kn`igonečatiiā A. Andrića.)

\section{Вујић, J. 1901}

Путешествије по Сербији I, Прва књига, Београд: Српска књижевна задруга.

(Vujić, J. 1901

Putešestvije po Serbiji I, Prva knjiga, Beograd: Srpska književna zadruga.)

\section{Влаић, Т. 1850}

Србский венацъ, одь народиьи србскій исторически и наравоучителиьл прича, песама, басна, пословица и загонетки исплетень, I часть, Београд: Печатано у Кньигопечатньи Кивжества Српскогь.

(Vlaić, T. 1850

Srbsklì venac,, , od' narodi'i srbskli istoričeski $i$ naravoučiteli'ı priča, pesama, basna, poslovica $i$ zagonetki ispleten', I čast', Beograd: Pečatano u Kn'igopečatn'i Kiržestva Srpskog'.)

Дероко, А. 1950

Средњовековни градови у Србији, Црној Гори и Македонији, Београд: Просвета.

(Deroko, A. 1950

Srednjovekovni gradovi u Srbiji, Crnoj Gori $i$ Makedoniji, Beograd: Prosveta.)

Драгашевић, J. 1874

Планине по Хомољу. Из путовања по Србији, Летопис Матице српске, књ. 116, Нови Сад, 59-90.

(Dragašević, J. 1874

Planine po Homolju. Iz putovanja po Srbiji, Letopis Matice srpske, knj. 116, Novi Sad, 59-90.)

\section{Драгашевић, J. 1876}

Принос за географију Србије. Млава и Пек, С картом Хомоља. Гласник Српског ученог друштва, књ. XLIII, Београд, 261-346.

(Dragašević, J. 1876

Prinos za geografiju Srbije. Mlava i Pek, S kartom Homolja. Glasnik Srpskog učenog društva, knj.

XLIII, Beograd, 261-346.)

\section{Dragojević, Č. 1983}

Muzej и Požarevcu. Istorijat. Današnje stanje $i$ perspektiva razvoja, Neobjavljen magistarski rad, Sveučilište u Zagrebu, Centar za postdiplomski studij.

Јацановић, Д. и Живковић, Ј. 2000

Археолошке „белешке“ Николе Крстића, Viminacivm 11, Пожаревац, 111-154.

(Jacanović, D. i Živković, J. 2000

Arheološke „beleške“ Nikole Krstića, Viminacivm 11, Požarevac, 111-154)

\section{Јацановић, Д. 2013}

Касноантичка налазишта у Браничеву, у: $O \partial$ Романа до Словена. Археолошки налази из Сpбије и ғихов контекст, Научни скуп у организацији Филозофског факултета у Београду, ур. М. Милинковић, књига апстракта радова са програмом скупа, Београд: Филозофски факултет у Београду, 13-14.

(Jacanović, D. 2013

Kasnoantička nalazišta u Braničevu, u: Od Romana do Slovena. Arheološki nalazi iz Srbije i njihov kontekst, Naučni skup u organizaciji Filozofskog fakulteta u Beogradu, ur. M. Milinković, knjiga apstrakta radova sa programom skupa, Beograd: Filozofski fakultet u Beogradu, 13-14.)

\section{Jevremović, N. 1987}

Keramika južnog i zapadnog bedema lokaliteta Diana - Karataš, Đerdapske sveske IV, Beograd: Arheološki institut, Narodni muzej Beograd i Odeljenje za arheologiju Filozfskog fakulteta u Beogradu, 49-70. 
Лудајић, Н., Поповић, С. и Милинковић, М. 1986

Резултати истраживања вишеслојног налазишта на локалитету Јеринин град - Горња Црнућа код Горњег Милановца, Зборник радова Народног музеја XVI, Чачак, 81-93.

(Ludajić, N., Popović, S. i Milinković, M. 1986

Rezultati istraživanja višeslojnog nalazišta na lokalitetu Jerinin grad - Gornja Crnuća kod Gornjeg Milanovca, Zbornik radova Narodnog muzeja XVI, Čačak, 81-93.)

\section{Каниц, Ф. 1985}

Србија, земља и становништво од римског доба до краја XIX века I, Београд: Српска књижевна задруга и Рад.

(Kanic, F. 1985

Srbija, zemlja i stanovništvo od rimskog doba do kraja XIX veka I, Beograd: Srpska književna zadruga i Rad.)

\section{Карић, В. 1997}

Србија, опис земье, народа и државе, Београд: Култура-Београд и Православна реч-Нови Сад. (Karić, V. 1997

Srbija, opis zemlje, naroda i države, Beograd: Kultura-Beograd i Pravoslavna reč- Novi Sad.)

\section{Kopah, М. 2018}

Касноантичка и рановизантијска утврђева Љубичеваи и Уиће Слатинске реке, Ђердапске свеске, посебна издања 8, Београд: Археолошки институт.

(Korać, M. 2018

Kasnoantička i ranovizantijska utvrđenja Ljubičevac i Ušće Slatinske reke, Đerdapske sveske, posebna izdanja 8, Beograd: Arheološki institut.)

\section{Мадас, Д. и Гајић, А. 1983}

Надгробне плоче и гробови ктитора цркве Богородице Пречисте у комплексу Ждрела у Горњачкој клисури, Саопштењ $\mathrm{XV}$, Београд, 221-242.

(Madas, D. i Gajić, A. 1983
Nadgrobne ploče i grobovi ktitora crkve Bogorodice Prečiste u kompleksu Ždrela u Gornjačkoj klisuri, Saopštenja XV, Beograd, 221-242.)

\section{Манојловић, М. 2001а}

Извештај о раду Народног музеја за 1999. годину, Viminacivm 12, Пожаревац, 329-332.

(Manojlović, M. 2001a

Izveštaj o radu Narodnog muzeja za 1999. godinu, Viminacivm 12, Požarevac, 329-332.)

\section{Манојловић, М. 2001b.}

Извештај о раду Народног музеја у Пожаревцу за 2000 годину, Viminacivm 12, Пожаревац, 332-333.

(Manojlović, M. 2001b.

Izveštaj o radu Narodnog muzeja u Požarevcu za 2000 godinu, Viminacivm 12, Požarevac, 332-333.)

Марковић, О., Петрашиновић М. и Михајловић, В. 1986

Резултати сондажних истраживања Стојковића градине у Вичи, Зборник радова Народног Музеја XVI, Чачак, 67-72.

(Marković, O., Petrašinović M. i Mihajlović, V. 1986

Rezultati sondažnih istraživanja Stojkovića gradine u Viči, Zbornik radova Narodnog Muzeja XVI, Čačak, 67-72.)

\section{Марковић, J. 1988}

Енциклопедијски географски лексикон Југославије, Сарајево: SUOR Svjetlost Sarajevo. (Marković, J. 1988

Enciklopedijski geografski leksikon Jugoslavije, Sarajevo: SUOR Svjetlost Sarajevo.)

Милинковић, М. 2015

Рановизантијска насеља у Србији и юеном окружењу, Београд: Досије студио.

(Milinković, M. 2015

Ranovizantijska naselja u Srbiji $i$ njenom okruženju, Beograd: Dosije studio.) 
Милићевић, М. 1867

Манастири у Србији од М. Ђ. Милићевића,

Гласник Српског ученог друштва IV, св. XXI (старога реда), Београд, 1-97.

(Milićević, M. 1867

Manastiri u Srbiji od M. Đ. Milićevića, Glasnik Srpskog učenog društva IV, sv. XXI (staroga reda), Beograd, 1-97.)

\section{Милићевић, М. 1876}

Кнежевина Србија, Београд: Државна штампарија.

(Milićević, M. 1876

Kneževina Srbija, Beograd: Državna štamparija.)

Миловановић, М. 2016а

Браничево у рановизантијском периоду на основу археолошких налаза, Мастер рад, Филозофски факултет, Универзитет у Београду.

(Milovanović, M. 2016a

Braničevo u ranovizantijskom periodu na osnovu arheoloških nalaza, Master rad, Filozofski fakultet, Univerzitet u Beogradu.)

\section{Миловановић, М. 2016b}

Рановизантијски локалитети у Хомољу, Хабилитациони рад, Народни музеј Београд.

(Milovanović, M. 2016b

Ranovizantijski lokaliteti u Homolju, Habilitacioni rad, Narodni muzej Beograd.)

\section{Миловановић, М. 2017}

Рановизантијски локалитети у околини Жагубице, Браничевски гласник 11, Пожаревац, 29-46.

(Milovanović, M. 2017

Ranovizantijski lokaliteti u okolini Žagubice, Braničevski glasnik 11, Požarevac, 29-46.)

\section{Миловановић, М. 2018а}

Рановизантијски локалитет Пчелињи крш (Крш ку албина) у Лазници код Жагубице, у: Рановизантијски период у околини Жагубице. Преглед археолошких налаза, ур. М. Миловановић и О. Филиповић, Жагубица: Завичајни музеј Хомоља у Жагубици, 7-10.

(Milovanović, M. 2018a

Ranovizantijski lokalitet Pčelinji krš (Krš ku albina) u Laznici kod Žagubice, u: Ranovizantijski period u okolini Žagubice. Pregled arheoloških nalaza, ur. M. Milovanović i O. Filipović, Žagubica: Zavičajni muzej Homolja u Žagubici, 7-10.)

\section{Milovanović, M. 2018b}

Two Early Byzantine Fibulae from the Pčelinji krš Site in Laznica near Žagubica, Archaeology and Science 14, Belgrade, 29-38.

\section{Миловановић, М. (in print)}

Историјат истраживања археолошких налазишта и средњовековних црквених споменика у Хомољу, Хомољски зборник 1, Жагубица: Завичајни музеј Хомоља у Жагубици.

(Milovanović, M. (in print)

Istorijat istraživanja arheoloških nalazišta i srednjovekovnih crkvenih spomenika u Homolju, Homoljski zbornik 1, Žagubica: Zavičajni muzej Homolja u Žagubici.)

\section{Миловановић, М. и Филиповић, О. 2018}

Рановизантијски периоду у околини Жагубице и смернице ка даљим истраживањима, у: Рановизантијски период у околини Жагубище. Преглед археолошких налаза, ур. М. Миловановић и О. Филиповић, Жагубица: Завичајни музеј Хомоља, 2-6.

(Milovanović, M. i Filipović, O. 2018

Ranovizantijski periodu u okolini Žagubice i smernice ka daljim istraživanjima, u: Ranovizantijski period u okolini Žagubice. Pregled arheoloških nalaza, ur. M. Milovanović i O. Filipović, Žagubica: Zavičajni muzej Homolja, 2-6.)

\section{Мишић, С. и Селаковић, М. 2017}

Средњовековно насеђе на тлу Хомоља, Браничевски гласник 11, Пожаревац, 17-25.

(Mišić, S. i Selaković, M. 2017

Srednjovekovno naseđe na tlu Homolja, Braničevski glasnik 11, Požarevac, 17-25.) 
Младеновић, Б. и Јацановић, Д. 2002.

Насеља Браничева. Географско - археолошко

- историјска монографија, Пожаревац: НИГП „Радојковић“-Смедерево и COTOS Пожаревац. (Mladenović, B. i Jacanović, D. 2002.

Naselja Braničeva. Geografsko - arheološko - istorijska monografija, Požarevac: NIGP „Radojković““- Smederevo i COTOS Požarevac.)

\section{Nikolić-Đorđević, S. 2000}

Antička keramika Singidunuma. Oblici posuda, Singidunum 2, Beograd, 11-244.

\section{Петковић, В. 1935}

Геологија Источне Србије, Српска краљевска академија, Посебна издања, књига 1, Београд: Задужбина Каменка и Павла Браће Јовановића 9, 1-213.

(Petković, V. 1935

Geologija Istočne Srbije, Srpska kraljevska akademija, Posebna izdanja, knjiga 1, Beograd: Zadužbina Kamenka i Pavla Braće Jovanovića 9, 1-213.)

\section{Поповић, К. 1867}

Пут лицејских питомаца (јестаственичког одељења) по Србији године 1863., Београд: Државна штампарија.

(Popović, K. 1867

Put licejskih pitomaca (jestastveničkog odeljenja) po Srbiji godine 1863., Beograd: Državna štamparija.)

\section{Popović, M. 1999}

Tvrđava Ras, Posebna izdanja 34, Beograd: Arheološki institut Beograd.

\section{Радичевић, Д. 2006}

Археолошка истраживања на Лишкој Ћави код Гуче у 2002. и 2006. години, Зборник радова Народног музеја Чачак, XXXVI, 31-37.

(Радичевић, Д. 2006

Археолошка истраживања на Лишкој Ћави код Гуче у 2002. и 2006. години, Зборник радова Народног музеја Чачак, XXXVI, 31-37.)
Радовановић, Д. 1997

Археолошка налазишта са сакралним садржајем на подручју Подунасвког и Браничевског округа, у: Споменичи Смедеревља и Браничева 1, ур. Н. Јоцовић, Смедерево: Регионални завод за заштиту споменика културе Смедерево, 235-256.

(Радовановић, Д. 1997

Археолошка налазишта са сакралним садржајем на подручју Подунасвког и Браничевског округа, у: Споменици Смедеревља и Браничева 1, ур. Н. Јоцовић, Смедерево: Регионални завод за заштиту споменика културе Смедерево, 235-256.)

\section{Ризнић, Ст. М. 1886}

Манастир Горњак, Старинар, година III, 59-64. (Riznić, St. M. 1886

Manastir Gornjak, Starinar, godina III, 59-64.)

\section{Ризнић, Ст. М. 1888}

Старински остаци у срезу звишком (окр. пожаревачки), Старинар, година V, Београд, 31-39.

(Riznić, St. M. 1888

Starinski ostaciu srezu zviškom(okr. požarevački), Starinar, godina V, Beograd, 31-39.)

\section{Старинар I,}

Старинар Српског археолошког друштва, Година I, 1884, Београд.

(Starinar I,

Starinar Srpskog arheološkog društva, Godina I, 1884, Beograd.)

Стојић, М. и Јацановић, Д. 2008

Пожаревац. Културна стратиграфија праисторијских локалитета у Браничеву, Археолошка грађа Србије IV, Београд - Пожаревац: Археолошки институт Београд и Народни музеј Пожаревац.

(Stojić, M. i Jacanović, D. 2008

Požarevac. Kulturna stratigrafija praistorijskih lokaliteta u Braničevu, Arheološka građa Srbije IV, 
Beograd - Požarevac: Arheološki institut Beograd i Narodni muzej Požarevac.)

\section{Цвјетићанин, Т. 2016}

Касноримска керамика Ђердапа, Археолошке монографије 24, Београд: Народни музеј.

(Cvjetićanin, T. 2016

Kasnorimska keramika Đerdapa, Arheološke monografije 24, Beograd: Narodni muzej.)

\section{Цуњак, М. и Миљковић, М. 1992}

Горњачко - рибарска клисура у светлу археолошких истраживања, Гласник друштва конзерватора Србије 16, 101-104.

(Cunjak, M. i Miljković, M. 1992

Gornjačko - ribarska klisura u svetlu arheoloških istraživanja, Glasnik društva konzervatora Srbije 16, 101-104.)

\section{Цуњак, М. 2000}

Светиње Горњачке клисуре, Смедерево: Скупштина Општине Жагубица; Скупштина Општине Петровац на Млави и Завичајни музеј Петровац на Млави.

(Cunjak, M. 2000

Svetinje Gornjačke klisure, Smederevo: Skupština Opštine Žagubica; Skupština Opštine Petrovac na Mlavi i Zavičajni muzej Petrovac na Mlavi.)
REZIME

ARHEOLOŠKI LOKALITET GRAC - GORNJAČKI IZVOR U GORNJAČKOJ KLISURI

\section{KLJUČNE REČI: GORNJAČKA KLISURA, FORTIFIKACIJA, VRH GRAC, KASNA ANTIKA, RANA VIZANTIJA.}

Ostaci fortifikacija i sakralnih spomenika na širem području Gornjačke klisure, nedaleko od Petrovca na Mlavi, u hronološkom smislu se u našoj nauci opredeljuju u vreme poznog srednjeg veka. Rezultati arheoloških rekognosciranja, koja su u nekoliko navrata vršena na ovom prostoru, ukazuju i na naseljavanje tokom kasnoantičkog i ranovizantijskog perioda. U ovom radu je predstavljen arheološki lokalitet Grac - Gornjački izvor koji se nalazi u samom središtu Gornjačke klisure, i njegova bliža okolina. Vidljivi ostaci odbrambenog zida nalaze se na levoj obali reke Mlave, ispred poznosrednjovekovnog manastira Gornjak, odnosno na istočnim obroncima vrha Grac koji predstavlja jedan od visova planine JeŽevac. Na suprotnoj strani Mlave, tačnije preko puta samog lokaliteta, nalazi se Gornjački izvor. Odbrambeni zid je sagrađen na stenovitom grebenu, na nadmorskoj visini od oko $160 \mathrm{~m}$. Putopisci druge polovine 19. veka ostavili su podatke o fortifikacijama na Ježevcu i levoj obali Mlave, ali ne možemo sa sigurnošću reći da li su oni obišli zid koji je predstavljen u ovom radu. Pedesetih godina 20. veka, N. Krstić iz Petrovca na Mlavi, zaljubljenik u starine i saradnik požarevačkog Muzeja, ostavlja značajne podatke o odbrambenom zidu ispred manastira. Sudeći po prikupljenim nalazima, lokalitet Grac-Gornjački izvor je bio naseljen u periodu 4-6. veka, ne isključujući mogućnost naseljavanja i tokom drugih perioda istorije. Budući da je lokalitet podložan destrukciji od strane ilegalnih tragača, cilj ovog rada je, pre svega, da ukaže na potrebu za zaštitnim arheološkim iskopavanjima, kako ostaci fortifikacija ne bi bili u potpunosti uništeni, a kulturni slojevi poremećeni. 